\title{
Selvmordforebygging skal sitte i veggene: Om bygging av nytt Østfoldsykehus
}

Ved Kari Gjelstad og Kim Larsen

\section{Studiet i arkitekturens sosialpsykologi viser at arkitekturen er avgjørende for å fremkalle bestemte mønstre av menneskelig interaksjon. Ved bygging av psykiatriske avdelinger vil det å ikke være bevisst arkitekturens tause språk i ekstreme tilfeller kunne bety forskjellen mellom liv og død. I artikkelen presenterer vi konkrete eksempler på hvordan man kan balansere mellom selvmordsforebyggende tiltak og hensynet til trivsel og terapeutisk rom.}

\begin{abstract}
Planlegging av bygging og innredning av psykiatriske akuttavdelinger er en prosess som fordrer et blikk for arkitekturens rolle i å påvirke menneskelig adferd og samspill, og bevissthet om viktigheten av arkitektur og innredning $\mathrm{i}$ det selvmordsforebyggende arbeidet. En psykiatrisk avdeling skal ha høy grad av sikkerhet mot mulighet for villet egenskade og selvmord, samtidig som den skal gi gode rammer for terapeutisk arbeid og ivareta pasientenes privatliv og integritet på best mulig måte. Artikkelen beskriver erfaringer fra planleggingen av nytt Østfoldsykehus, og gir eksempler på de prosesser og avveininger som legger grunnlag for utforming av bygg og lokaler, samt for valg av materialer og utstyr i en psykiatrisk avdeling.
\end{abstract}

The planning of the construction and furnishing of acute psychiatric wards demands a keen eye for the role of architecture in influencing human behaviour and interaction, and an awareness of the importance of architecture and fixtures in suicide prevention. A psychiatric ward needs a high standard of security to prevent deliberate self-harm and suicide. At the same time, the ward should provide a good location for therapeutic work, and respect the patients' integrity and need for privacy. The paper describes experiences from the planning of a new hospital in Østfold county, and presents examples from the process of cooperation between builder, architects and psychiatric personnel in the construction and furnishing of the psychiatric ward at a new hospital. The paper focuses on the design of the building and facilities as well as choice of materials, fixtures and furniture.

\section{Innledning}

Studiet av arkitekturens sosialpsykologi er unison i å vise at arkitekturen er avgjørende for å fremkalle bestemte mønstre av menneskelig interaksjon (Barker, 1968; Hall, 1966; Sommer, 1969). Disse typiske interaksjonelle mønstre skapes på en måte som vanligvis er usynlig og ubevisst for oss. Det er således ingen tilfeldighet at antropologen Edward T. Hall, en pioneer i studiet av hvordan arkitekturen påvirker og mønstrer det menneskelige samspill som forekommer innenfor de rammene arkitekturen setter, kalte sin mest kjente bok The hidden dimension (1966). Imidlertid vektlegges ofte først de åpenbare økonomiske kostnadene ved bygging og konstruksjon, og senere driftsmessige hensyn som renhold, oppvarming osv., framfor hensyn til de mer subtile effektene arkitekturen har på menneskelig samspill. Men det finnes noen unntak. Ett av dem er bygging og innredning av psykiatriske akuttavdelinger med tanke på selvmordsforebygging (se for eksempel Bergsland, 2008), hvor bevisstheten om arkitekturens tause språk i ekstreme tilfeller vil kunne bety forskjellen mellom liv og død. Ved Sykehuset Telemark har det blitt utført et pionerarbeid når det gjelder hensiktsmessig bygging og innredning av en psykiatrisk avdeling (Burt-0`Dea, 2005, Larsen, 2005).

I Nasjonale retningslinjer for forebygging av selvmord i psykisk helsevesen (Helsedirektoratet, 2008) gis det et forslag til prosedyre: "Fysisk sikring av døgnenheter i forhold til forebygging av selvmord". Prosedyren legger særlig vekt på å fjerne ligaturpunkter:
- Gardinoppheng

- Dusjarmaturer

- Lysarmaturer

- Dør-, vindus- og skaphåndtak

- Listverk

- Rør eller pipeløp

- Møbler

Prosedyren anbefaler videre følgende fysiske sikringstiltak:

- Sikring av vinduer og trappehus mot utsprang

- Sikring av dører mot rømming

- Sikring av dører mot blokkering i pasientrom (dører må svinge utover, ikke innover)

Prosedyren avsluttes med å påpeke viktigheten av at bygningene bør være tilpasset slik at observasjon av pasienter $i$ selvmordsrisiko kan foretas både på en forsvarlig og en mest mulig skånsom måte.

Som en del av National confidential inquiry into homicide and suicide in England and Wales ble alle selvmordene som ble utført inne på psykiatriske avdelinger i tidsperioden fra og med 1999 til og med 2007 analysert (Hunt et. al., 2012). Følgende funn er relevante for våre formål: "De vanligste ligaturpunktene var dører, kroker, eller håndtak, og vinduer, som til sammen representerte $59 \%$ av alle festepunkter. Ti prosent av pasientene benyttet seng, $8 \%$ benyttet stenger som var en del av faste installasjoner (dusj, toalett, eller garderobe), $6 \%$ benyttet rør og $3 \%$ benyttet gardinstenger. I 33 (10\%) tilfeller ble andre festepunkter benyttet, inkludert dusjarmatur og kraner, lysarmatur og radiatorer. 


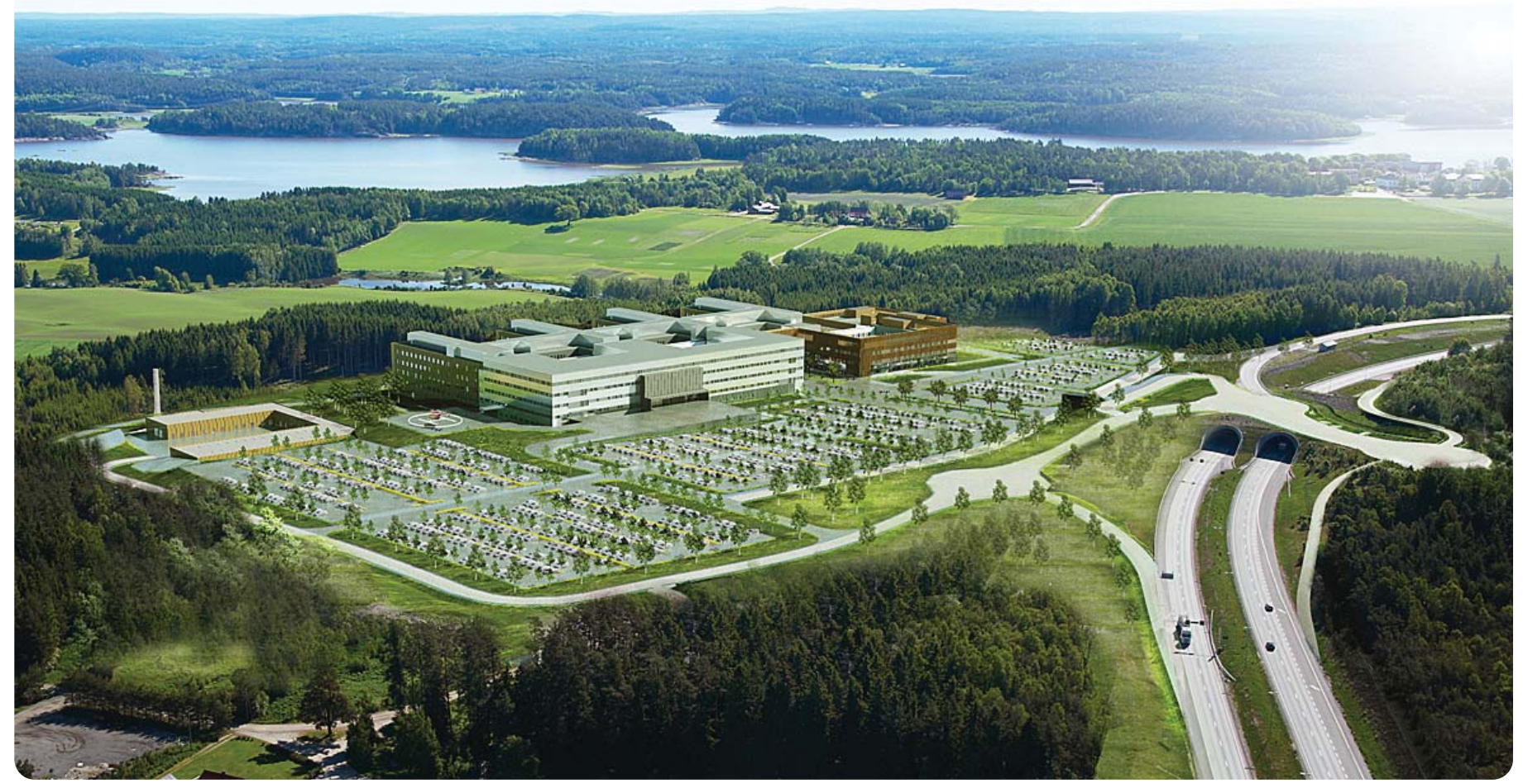

Nytt Østfoldsykehus er lokalisert ved Kalnes, nordvest for Sarpsborg, mellom Moss og Halden. I bakgrunnen Vestvannet og Tunevannet. E6 lengst til høyre.

$\mathrm{Ni}$ (3 \%) pasienter benyttet manuell strangulering som ikke krevde et festepunkt" (s. 90. Vår oversettelse). Når det gjelder gjenstander som ble benyttet for henging (ligaturer), var disse i $73 \%$ av tilfellene brakt inn i institusjonen av pasienten selv som en del av personlige eiendeler (for eksempel bagasjestropper, tau, ledninger fra portabelt lydutstyr). Totalt sett var de vanligste ligaturer: belter, laken eller håndklær som stod for $61 \%$ av all ligatur, skolisser (12\%), deler av klesplagg (12\%), og annet som for eksempel telefonledning, tau, fjernsynskabel, ryggsekkrem/snøre og gardiner. Over halvparten (53\%) av hengingene skjedde på pasientrom og ca. en fjerdedel (27 \%) på toalett eller baderom.

En tendens i materialet var at bruk av henging/strangulering som metode var gått ned relativt til andre metoder for selvmord utført i psykiatriske institusjoner i perioden, fra 57 i 1999 (28 \% av alle selvmord i psykiatriske institusjoner) til $15(14 \%)$ i 2007. Forfatterne fant også at bruken av festepunkter og ligatur forandret seg over tid, delvis som følge av tidligere tiltak. Eksempelvis ble faste gardinstenger $\mathrm{i}$ forheng rundt senger påbudt fjernet i løpet av studieperioden av National Institute for Mental Health in England, 2003.

En psykiatrisk avdeling må, av grunner beskrevet i forrige avsnitt, ha fokus på høy grad av sikkerhet mot mulighet for villet egenskade og selvmord, samtidig som den skal gi gode rammer for terapeutisk arbeid og ivareta pasientenes privatliv og integritet på best mulig måte. Artikkelen beskriver erfaringer fra planleggingen av nytt Østfoldsykehus, og gir eksempler på de prosesser og avveininger som legger grunnlag for utforming av bygg og lokaler, samt for valg av materialer og utstyr i en psykiatrisk avdeling.

\section{Bakgrunn}

Østfold er i den privilegerte situasjon at man i mai 2015 begynner innflytting i et helt nybygd fylkesdekkende sykehus.

Psykiatrisk avdeling er en bygningsmessig integrert del av nybygget, og siden 2009 har ansatte fra Klinikk for psykisk helse- vern deltatt aktivt i arbeidsgrupper som har vært med på utformingen. Arbeidsgruppene har bestått av representanter fra eksterne aktører innen byggebransje og arkitektur, Prosjekt nytt Østfoldsykehus, Sykehuset Østfolds ledelse og sykehusansatte. Deltakelse med hensyn til myndighet, fagbakgrunn og antall har variert etter hvor i prosessen man har vært. Gruppen fra Klinikk for psykisk helsevern har inkludert avdelingssjef for psykiatrisk akuttavdeling som er psykiater, seksjonsledere fra henholdsvis langtidsseksjon, akuttseksjon og sikkerhetsseksjon, assisterende seksjonsleder fra psykiatrisk akuttmottak og assisterende avdelingssjef for psykiatrisk intermediæravdeling, alle sykepleiere med spesialutdanning i psykiatri og med lang erfaring i drift av og behandling i døgnseksjoner. Avdelingssjefen var leder for sykehusdelen av gruppen, og hadde som funksjon å være kontaktperson overfor byggherre og arkitekter, samt sørge for at prosesser ikke stoppet opp. Det siste innebar i hovedsak å påse at kommunikasjon fortsatte selv om det 
forelå uenighet. Oppgaven viste seg til dels tidkrevende, men ikke vanskelig. Utforming av gode bygg er som alt annet avhengig av gode prosesser. Samarbeid mellom forskjellige faggrupper forutsetter at man kan klare å holde en dialog åpen til tross for forskjeller i språk, temperament og tempo.

Prosessen kan grovt sett deles i tre hovedfaser som igjen var delt opp i flere faser med økende detaljeringsnivå:

1. Utforming av bygg og lokaler

2. Valg av materialer

3. Valg av utstyr

\section{Utforming av bygg og lokaler}

Det har vært et tydelig ønske fra Klinikk for psykisk helseverns ledelse at klinikkens sykehusavdelinger skulle være en del av nytt Østfoldsykehus. I nåværende lokaler, Veums 100 år gamle bygninger, er nærhet til somatiske tjenester savnet og begrenser kvaliteten på tilbudet til pasientene.

Psykiatrisk avdeling i Nytt Østfoldsykehus vil bestå av psykiatrisk akuttmottak, seks bygningsmessige sengeposter, to sikkerhetsposter, alderspsykiatrisk post og ECTenhet ved sengepost for affektive lidelser, totalt 98 sengeplasser. Det har vært en utfordring i prosessen å få psykiatrisk avdeling integrert i et nytt sykehus der akuttfunksjon, korttidsbehandling og bygningsteknisk standardisering er nøkkelbegreper. Helsepersonell i arbeidsgruppen har hele tiden måtte vurdere når det har vært hensiktsmessig og mulig å være "som de andre", og når det har vært nødvendig å insistere på at sikkerhet og selvmordsforebygging forutsetter spesielle tilpasninger. Da sikrings- og sikkerhetstiltak har fått mye oppmerksomhet, har det med jevne mellomrom vært behov for å presisere at fokus på forebygging og reduksjon av risiko bygger på klinisk erfaring og kvalifisert verstefallstenkning. Lav frekvens av uønskede hendelser forutsetter god forebygging.

Mange avgjørelser vedrørende økonomi, antall kvadratmeter, bygningsmessige strukturer og tekniske løsninger blir avgjort før arbeidsgrupper kommer inn i bildet, eller blir avgjort i andre fora. Dersom man går inn i en arbeidsgruppe, må man akseptere at noen rammer er satt, og at man først etter hvert får vite hvilke disse er og hvilke elementer som kan forhandles om. Hvis ikke bruker man mye tid på fånyttes og potensielt irriterende og frustrerende arbeid. Utformingen innenfor gitte rammer bygger på det muliges kunst, og det har i perioder vært utfordrende å tenke kreativt "innenfor boksen". Arkitektene hadde fokus på funksjonalitet og estetikk, flater og lys. Helsepersonell var opptatt av funksjonalitet, oversikt og sikkerhet. Her ble det konstruktive diskusjoner rundt hva funksjonen til de forskjellige arealene skulle være. Vi erfarte at nesten ingen begreper er entydige, og at de noen ganger betyr helt konkret forskjellige ting for helsepersonell og arkitekter. For eksempel kan lys og glassvegger for noen bety oversikt og lys, for andre manglende avskjerming og fare for glassskår. Et begrep som sikkerhet kan være mangetydig også mellom helsepersonell. I alle diskusjoner om sikkerhet ble det nødvendig med avklaring rundt risiko og trygghet versus trivsel og godt terapeutisk rom. I disse diskusjonene gikk ikke alltid skillelinjene mellom forskjellige faggrupper, men også internt i faggruppene. Grunnlaget for en slik diskusjon er en erkjennelse av at et bygg i seg selv aldri kan gi $100 \%$ sikkerhet mot at pasienter skader seg. Fagpersoner fra psykisk helse vil mer ensidig holde fokus på å få utformingen av rom og utstyr så nær 100 \% sikkert som mulig, om nødvendig på bekostning av alle andre hensyn. Andre vil fokusere på at man også må ta med i vurderingen at et for sterilt og sikret lokale kan bidra til et for sterkt fokus på risiko for villet egenskade og selvmordsatferd. På den annen side vil lokaler som er varme og åpne, med fokus på trivsel, trolig kunne bidra til reduksjon av angst og aggresjon og derved redusere risikoatferd. Denne diskusjonen er grunnleggende viktig ved alle punkter i utformingen av en psykiatrisk avdeling.

Et eksempel på uenighet mellom arkitektonisk estetikk og hensynet til sikkerhet gjaldt nisjer ved inngang til pasientrom. Dette var et eksempel på et konkret bygningsmessig trekk som vakte helt forskjellige assosiasjoner og reaksjoner hos arkitektene og helsepersonell. Arkitektene ønsket nisjer for å bryte opp de lange korridorene. Helsepersonell ønsket ikke nisjer dype nok til at noen kunne stå der usett, da dette ville kunne medføre at det kunne være personer i korridoren uten at man hadde oversikt over det, og i den saken ble helsepersonellets vurdering av sikkerhet det avgjørende.

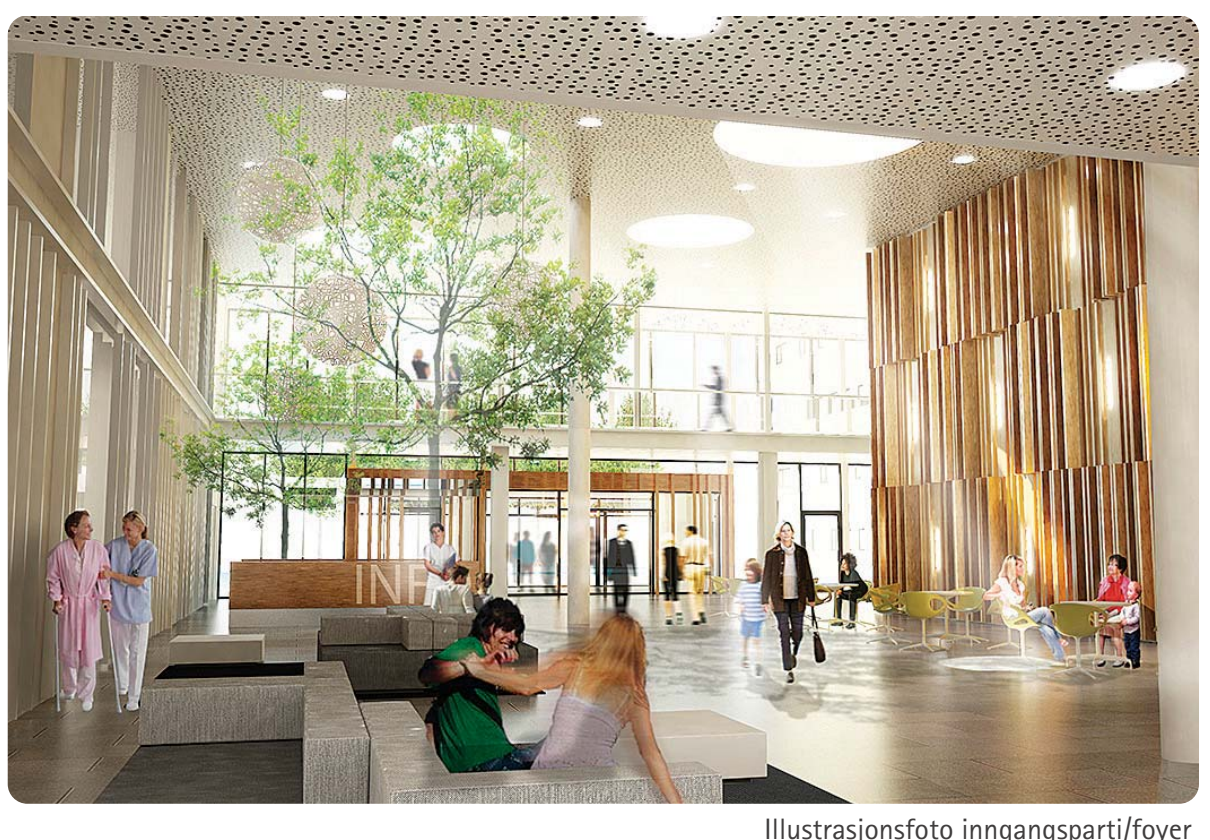


Figur 1. Planoversikt psykiatri 2. etg. Sikkerhetsnivåer i de forskjellige avdelingene i psykiatri

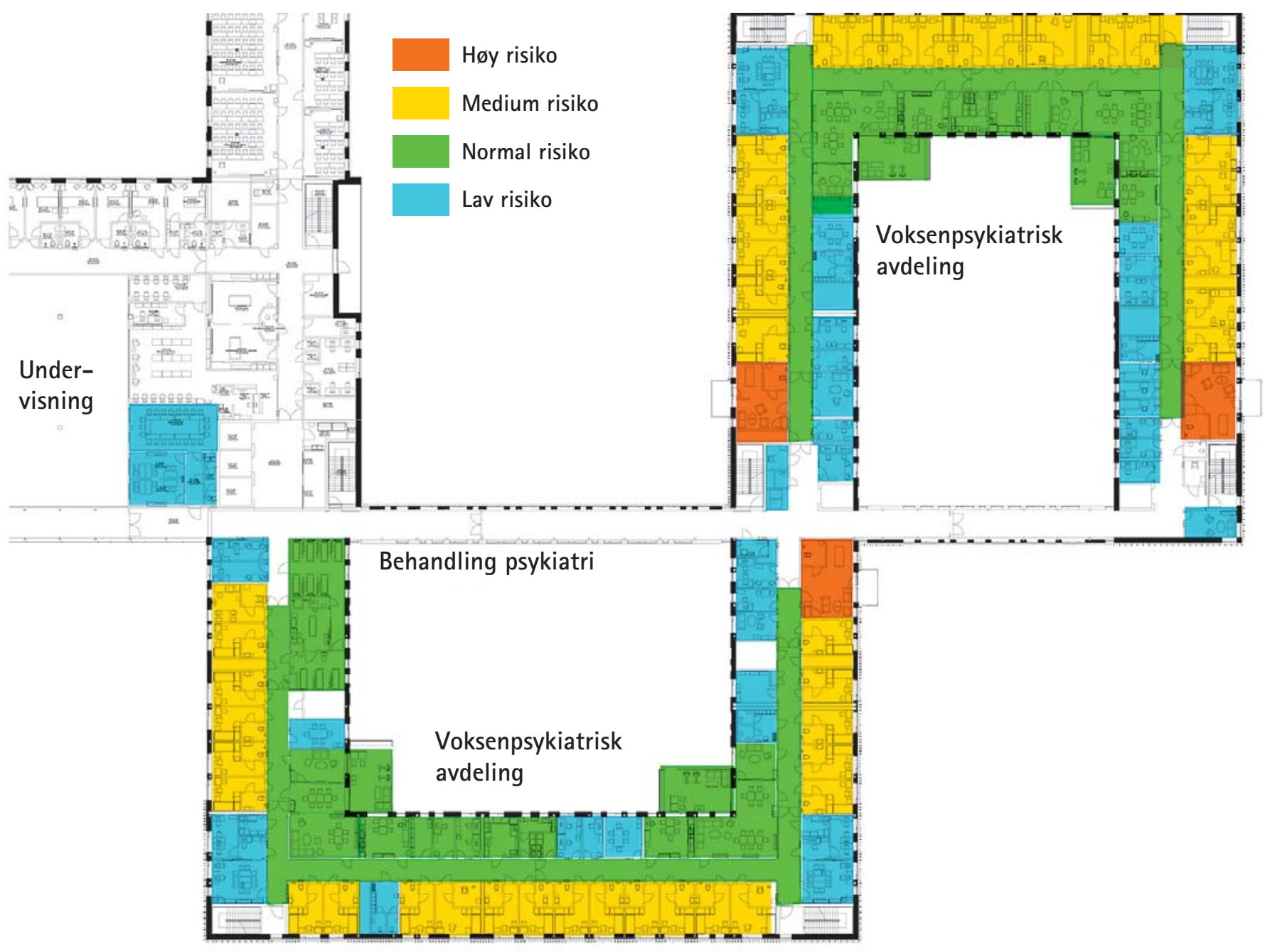

Noen endringer måtte vi forholde oss til fordi de var forskriftsstyrte. Dette var noen ganger svært utfordrende, som for eksempel da vi trodde fellesarealet var ferdig planlagt, og så fikk vite at det ikke er brannsikkerhetsmessig lovlig å ha så store åpne rom som vi ønsket i fellesarealet (Fig 2). En brannvegg midt i stua var verken hensiktsmessig eller estetisk heldig. Det ble imidlertid funnet løsninger da man gikk i diskusjon rundt rommets funksjon, og betydningen av åpenhet fikk stor tyngde. Løsningen ble en branngardin som vil bli senket ned fra taket ved behov. I bygging er det en målsetting å ha så mange standardrom som mulig, da dette gjør bygging billigere og planlegging enklere. Pasientrommene i psykiatrisk avdeling var satt med samme standard og dimensjoner som i somatiske sengeposter; det vil si romslige enerom med egne bad. Helsepersonell $\mathrm{i}$ arbeidsgruppen kom i den litt underlige posisjon at vi argumenterte for å redusere størrelsen på pasientrommene. Begrunnelsen var at vi ønsket å øke bredden på korridorene. I motsetning til somatiske pasienter som er innlagt for å ligge i seng, skal psykiatriske pasienter i hovedsak være oppe og ute i avdelingen det meste av våken tid. Bredere korridorer gir bedre oversikt for personalet og gir pasientene anledning til å unngå uønsket fysisk nærkontakt.

Det har vært en målsetting at postene skal være oversiktlige og romslige, slik at pasienter har størst mulig areal til å bevege seg fritt og trygt. Alle poster består av to korridorer som står vinkelrett på hverandre (Fig 1). Pasientenes oppholdsareal er plassert i innervinkel med utgang til stor veranda som ligger inn mot et atrium. Personalets vaktrom og kontorarbeidsplasser er plassert i yttervinkel slik at personalet har god oversikt over begge korridorer, og samtidig er naturlig tilgjengelig for pasientene i oppholdsarealet.
Oppholdsarealet er delt opp med halvvegger, for ikke å stenge for innsyn fra vaktrommet. Verandaene ligger inn mot atriet. De er sikret mot utsprang med sprinkelstruktur helt opp. Uheldig inntrykk av gitter er forsøkt dempet av flettverk og planter. Alle poster har skjermingsenheter som består av et større avdelt rom med bad. Disse har egne mindre altaner, som er sikret mot utsprang på samme måte som fellesaltanene. Det er eget aktivitetsrom i alle poster der pasienter, som ikke er skjermet, sammen med personale kan trekke seg tilbake fra fellesskapet.

Figur 1

Figur 1 viser to psykiatriske sengeposter. Til høyre psykiatrisk akuttmottak, til venstre en standardpost. Blå felt er personalområder, kontorer og aktivitets- og samtalerom. Gule felt er pasientrom. Røde felt er skjermingsenheter. 
Figur 2. Detalj av sengepost

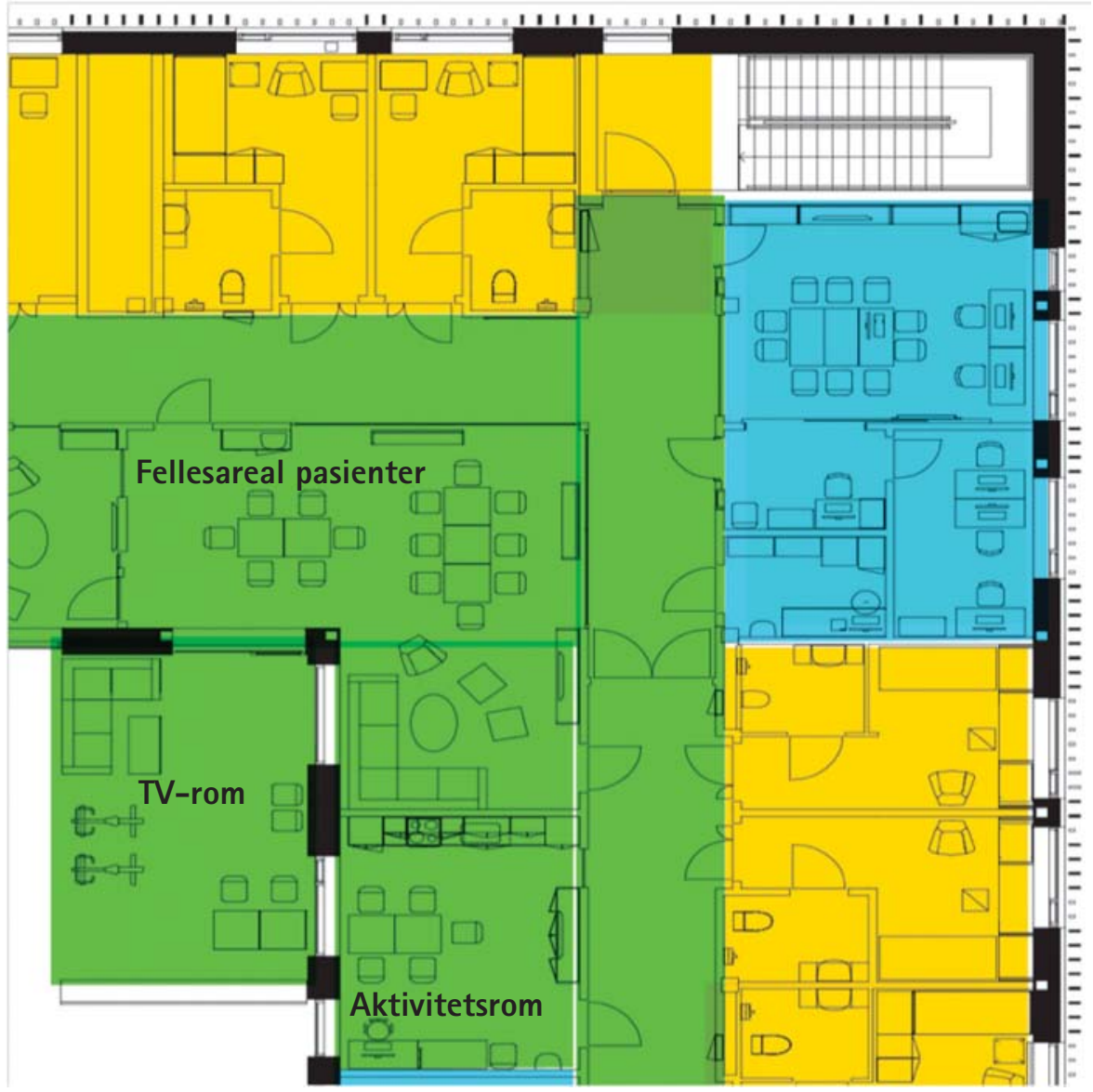

Figur 2 viser detalj av sengepost. Grønt område utgjør pasientenes fellesareal med altanen vendt inn mot atriet, korridor og oppholdsog spiserom, delt av med vegger i halvhøyde. Til venstre tv-rom med mulighet for avlukking. Nederst aktivitetsrom, med avlåst kjøkkeninnredning og pc til pasientbruk.

Sikring av byggets ytre rammer inkluderer også antall innganger, og for dette temaets del, utganger. Psykiatrisk avdeling er en integrert del av sykehuset, og postenes dører vender ut mot en korridor som løper gjennom hele sykehusets lengde. Postene skal kunne romme pasienter innlagt på tvang, og alle psykiatriske poster vil derfor være lukket. Antall dører ut av postene og ut av sykehuset er få. Ved systematisk gjennomgang av brann- og sikkerhetssystemer ble det oppdaget at psykiatrisk avdeling måtte ha egne tilpassete brannrutiner. Generelt på sykehuset vil alle dører åpne seg når brannalarmen går.
Dette ville være svært uheldig i forhold til rømningsfare, da dette også vil skje ved øvelser og falske alarmer. Det er nå laget egne brannrutiner for psykiatrisk avdeling som vil ivareta pasientenes sikkerhet både overfor brann- og rømningsfare.

\section{Materialvalg}

Materialvalg i forhold til risiko for villet egenskade og selvmord beskrives i nivåer av robusthet, der beskrivelsen "full vandalsikring" beskriver det høyeste nivået, som verken er miljømessig eller kostnadsmessig ønskelig. Vi har i klinikken hatt to eksempler på at for dårlige materialer har hatt tragisk utgang. En pasient løp gjennom en låst dør med vindu, og tok livet av seg. En annen pasient fikk opp et vindu og kastet seg ut fra andre etasje med dødelig utgang. Nytt bygg gir optimal mulighet for å tilpasse valg av materialer og utstyr til områdets funksjon. Arealene er delt inn i robusthetsnivåene høyt (rød: skjermingsenheter), medium (gul: sengerom, baderom, rom med lav himling), normalt (grønn: oppholdsrom, spiserom, grupperom) og lavt (blå: personalrom, medisinrom, kontorer, møterom, rengjøring og lager). Dette er illustrert i figurene $1 \mathrm{og}$ 2. Det vil for eksempel si at dører ut av postene og ut av skjermingsenhetene har høy robusthet, mens dørene inne i postene er relativt lette, men lydisolerende.

\section{Valg av utstyr}

Det har vært tilsvarende prosesser rundt valg av utstyr, som ved valg av bygningsmessige materialer. Vurdering av utstyr som lamper, gardinoppheng, baderomsarmatur og håndtak har på en måte vært enklere enn de bygningstekniske, fordi slike vurderinger ligger innenfor erfaringsområdet til helsepersonell som har erfaring fra psykiatriske sengeposter. I gamle bygg er det stort sett disse elementene man har mulighet til å kontrollere og justere.

Det har vært en nitid gjennomgang og testing av sikkerhet i forhold til lamper, radiatorer, garderobeoppheng og baderomsutstyr. Utstyr har blitt dratt i og kastet $\mathrm{i}$ veggen og evaluert av personell som har sett det meste av kreativitet når det gjelder å finne utstyr som gir mulighet for villet egenskade eller selvmord. Vi må innse at enerom og egne bad utgjør en forhøyet mulighet for villet egenskade eller selvmordsadferd, fordi det vil være naturlig at pasienter oppholder seg alene over lengre tid uten at dette vil vekke uro, dersom det ikke er bestemt tettere oppfølging. Dette stiller store krav til utstyr, særlig i forhold til å minimalisere ligaturpunkter. Alle pasientrom får kortlås så pasientene kan låse døren til egne rom slik at medpasienter ikke kan komme inn. Dørene slår utover for å forhindre barrikadering, og personalet kan åpne alle dører med sine kort. Med valg av utstyr som er evaluert etter robusthet, risiko og funksjonalitet vil både hensyn til pasientenes sikkerhet og deres behov for privatliv og integritet kunne ivaretas på best mulig måte. Nedenfor vises tre eksempler på installa- 
sjoner og utstyr valgt med fokus på å unngå ligaturpunkter og skarpe gjenstander. Eksemplene er hentet fra Prosjekt Nytt Østfoldsykehus, Helse Sør-Øst. På tilsvarende vis er alle detaljer vedrørende elektrisk anlegg, røropplegg, alarmsystem, glassflater, gardinoppheng, armaturer, møbler osv. evaluert.

Figur 3. Lysarmatur

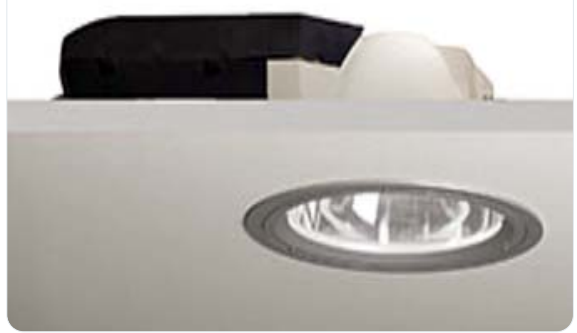

Ved lav himling på sengerom og på bad. Armaturen oppfyller kravene til beste mekaniske beskyttelse undenfra ifølge den internasjonale klassifiseringen IK10. IP 64 under himling/IP 20 over himling.

\section{Figur 4. Baderomsutstyr}

\section{$\mathrm{Bad} / \mathrm{WC}$ med høy robusthet}
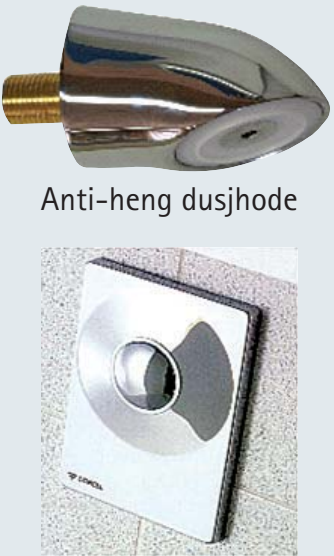

Spyleventil for WC

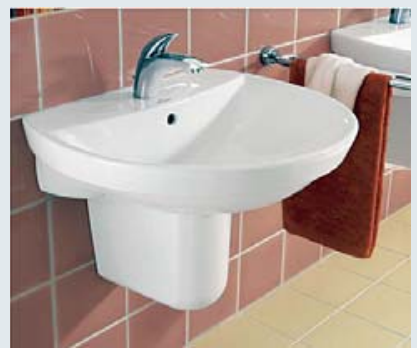

Porselenskappe under servant
Figur 5. Oppheng og håndtak til dører

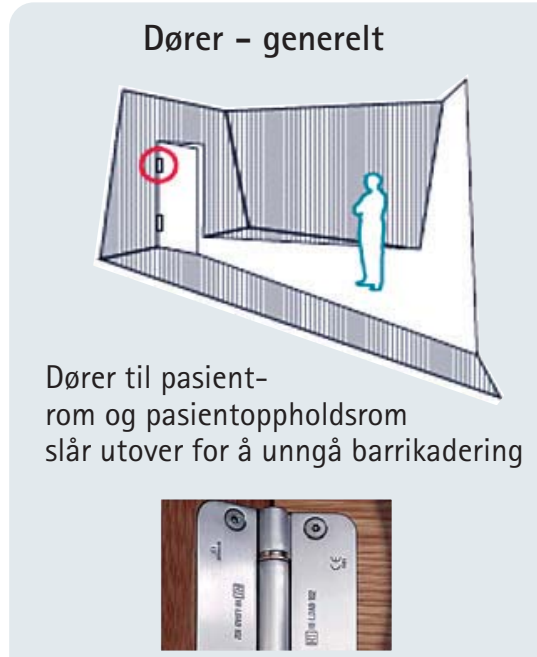

Innvendige dører utføres med forsterkede hengsler. Hengsler utføres slik at dører ikke kan demonteres uten bruk av verktøy

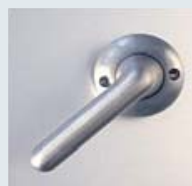

Dørhåndtak som peker skrått nedover og som umuliggjør feste av ligaturer

\section{Konklusjon}

Nytt bygg gir mulighet for at selvmordsforebygging kan sitte i veggene - både $\mathrm{i}$ konkret bygningsmessig og overført betydning. Et sikkert og hensiktsmessig bygg skaper en god ramme for både selvmordsforebygging og terapeutisk arbeid. Det forutsetter at helsepersonell med erfaring fra klinisk arbeid kommer inn i byggeprosesser på et tidlig tidspunkt og at det opparbeides et reelt samarbeid mellom faggrupper som ikke vanligvis arbeider sammen. Erfaringer fra planlegging av nytt Østfoldsykehus har vist at på sitt beste kan et slikt samarbeid bidra vesentlig til å finne kreative og praktiske løsninger. Det er en utfordring i en så omfattende og langvarig prosess å holde fokus både på det grunnleggende, det overordnede, og på detaljene. Dette er vi som fagpersoner trenet i gjennom langtidsoppfølginger av pasienter, der både historie, det eksistensielle og den konkrete vurdering av selvmordsrisiko alltid må ha fokus, men med vekslende intensitet.

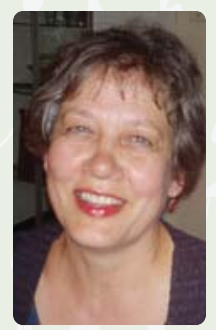

Kari Gjelstad er psykiater og gruppeanalytiker. Hun er avdelingssjef for psykiatrisk akuttavdeling, Sykehuset Østfold, og har vært leder for medarbeidergruppe psykiatri under planlegging av Nytt Østfoldsykehus.

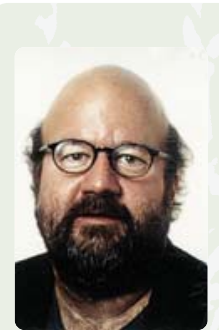

Kim Larsen er psykologspesialist ved Sykehuset Østfold og RVTS/Ø og arbeider også ved NSSF. Han er spesialist i klinisk samfunnspsykologi og arbeids- og organisasjonspsykologi. Faglige spesialinteresser er: sosialpsykologi, Freudbiografi og psykoanalysens historie, psykiatrihistorie og suicidologi.

\section{Referanser}

Barker, R. (1968). Ecological psychology: concepts and methods for studying the environment of human behavior. Stanford: Stanford University Press. Bergsland, K. (2008). Kan gode bygg bidra til psykiatrisk behandling? Suicidologi. Vol.13, No. 2, s. 3-5.

Burt-0'Dea, K. (2005). The design impact study. Durham: European Health Property Network.

Hall, E.T. (1966). The hidden dimension. New York: Doubleday.

Hunt, I.M. et. al. (2010). Ligature points and ligature types used by psychiatric inpatients who die by hanging. A national study. Crisis. Vol. 33, s. 87-94. Larsen, Jens-Erik (2005). Helsetrengende arkitektur. Psykisk helse, Nummer 1, s. 20-22.

Nasjonale retningslinjer for forebygging av selvmord i psykisk helsevern. (2008). Oslo: Helsedirektoratet.

National institute for mental health in England. (2003). The national suicide prevention strategy for England: Annual report on progress. Leeds.

Sommer, R. (1969). Personal space. Englewood Cliffs: Prentice-Hall.

IIllustrasjoner og bilder er hentet fra Prosjekt nytt Østfoldsykehus, Helse Sør-Øst RHF, ved Arkitektgruppen for nytt Østfoldsykehus og rådgivende ingeniører, Cowi. Presentasjon av prosjekterte løsninger. 15.02.2012. 